\title{
Small bowel obstruction after a capsule enteroscopy
}

\author{
James Richards, ${ }^{1}$ Amy Wass ${ }^{2}$
}

${ }^{1}$ Centre for Inflammation Research, University of Edinburgh, Edinburgh, UK ${ }^{2}$ Department of Medicine, Hawke's Bay Hospital, Hastings, New Zealand

\section{Correspondence to} James Richards, jamesrichards@doctors.net.uk

\section{DESCRIPTION}

A 74-year-old woman with a history of Crohn's disease, presented with colicky abdominal pain, absolute constipation and vomiting a week after capsular enteroscopy, performed as part of investigation of faecal occult blood positive anaemia. Her physiological parameters were within normal limits, abdomen was distended, but non-tender, and there were no clinically apparent hernias. She had no history of gastrointestinal surgery or other significant medical history. Abdominal $\mathrm{x}$-ray revealed the classical radiological features of small bowel obstruction proximal to the capsule (figure 1).

Wireless capsular enteroscopy is being increasingly used to investigate the small bowel, particularly in cases of obscure gastrointestinal bleeding, defined as bleeding from the gastrointestinal (GI) tract, which persists or recurs without an obvious cause identified upon upper GI endoscopy, colonoscopy or radiological examination of the small bowel. ${ }^{1}$ The capsule is small enough to be swallowed (approximately $11 \times 27 \mathrm{~mm}$ ), although about $10 \%$ report difficulty with this. There is a risk of capsule retention of about $1.9 \%$ (retention of capsule $>2$ weeks) or obstruction; this may resolve spontaneously, as in this case, or require intervention. Rates of retention and obstruction may be higher in certain patient groups, such as those with Crohn's disease, owing to the presence of strictures $^{2}$; Crohn's stricture was a contributing factor in this case.

In the first instance, contact should be made with the local capsule enteroscopy service for further advice. Double balloon enteroscopic capsule retrieval may be possible in simple capsule retention, thereby negating the need for any surgical intervention.

\section{Learning points}

- The use of wireless capsule enteroscopy has increased significantly in recent years, becoming the 3rd-line investigation for obscure gastrointestinal(GI) bleeding after upper $\mathrm{GI}$ endoscopy and colonoscopy. ${ }^{1}$

- Capsule retention occurs in 1-2\% of patients, though may be higher in certain groups (e.g. Crohn's disease).

- Obstruction and capsule retention may resolve spontaneously or require intervention (surgical or endoscopy); advice should be sought from the local capsule enteroscopic service.

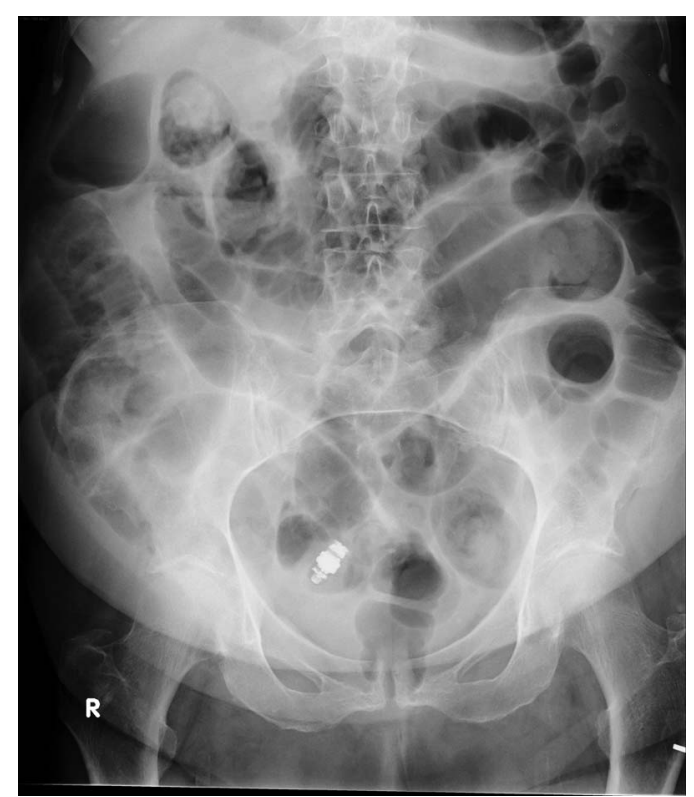

Figure 1 The capsule is seen in the right iliac fossa of this plain abdominal x-ray, with the proximal small bowel demonstrating the classical features of obstruction (dilated loops of centrally located bowel with visible valvulae conniventes).

\section{Competing interests None.}

Patient consent Obtained.

Provenance and peer review Not commissioned; externally peer reviewed.

\section{REFERENCES}

1 Sidhu R, Sanders D, Morris AJ, et al. Guidelines on small bowel enteroscopy and capsule endoscopy in adults. Gut 2008;57:125-36.

2 Szold A, Katz LB, Lewis BS. Surgical approach to occult gastro-intestinal bleeding. Gastroenterology 2005;128:1424-30.
To cite: Richards J, Wass A. BMJ Case Rep Published online: [please include Day Month Year] doi:10.1136/ bcr-2013-008606 
Copyright 2013 BMJ Publishing Group. All rights reserved. For permission to reuse any of this content visit http://group.bmj.com/group/rights-licensing/permissions.

BMJ Case Report Fellows may re-use this article for personal use and teaching without any further permission.

Become a Fellow of BMJ Case Reports today and you can:

- Submit as many cases as you like

- Enjoy fast sympathetic peer review and rapid publication of accepted articles

- Access all the published articles

- Re-use any of the published material for personal use and teaching without further permission

For information on Institutional Fellowships contact consortiasales@bmjgroup.com

Visit casereports.bmj.com for more articles like this and to become a Fellow 